\title{
Synthesis of novel enantiopure ionic liquids from $(S)$-malic acid
}

\author{
Marco Bonanni, Massimo Manuelli, Andrea Goti, Cristina Faggi, and Francesca Cardona* \\ Dipartimento di Chimica "Ugo Schiff”, Università degli Studi di Firenze, \\ Via della Lastruccia 13, 50019 Sesto Fiorentino (FI), Italy \\ E-mail: francesca.cardona@unifi.it
}

Dedicated to Prof. Pierre Vogel on the occasion of his $70^{\text {th }}$ birthday

DOI: $\underline{\text { http://dx.doi.org/10.3998/ark.5550190.p008.210 }}$

\begin{abstract}
A straightforward and practical synthesis of six novel pyrrolidinium salts based on $(S)$-malic acid is reported. Two of them were liquid at room temperature, and can be employed as novel chiral ionic liquids for enantioselective applications.
\end{abstract}

Keywords: Synthesis, malic acid, chiral ionic liquids, pyrrolidinium salts

\section{Introduction}

The interest of the scientific community in room temperature ionic liquids (RTILs) has grown enormously during the past 15 years, as attested by the impressive number of articles published and referenced in several reviews and books since $1999 .{ }^{1-8}$ Ionic liquids have attracted attention not only as alternative solvents for synthesis and catalysis but also, more recently, as innovative media for the deconstruction of lignocellulosic biomass ${ }^{9}$ and for use in biodiesel production. ${ }^{10}$ In particular, chiral ionic liquids (CILs) are of special interest as reaction media for asymmetric organic reactions, chiral discrimination, analytical chemistry. ${ }^{11-18}$ The possibility of obtaining novel chiral ionic liquids from renewable natural compounds ${ }^{19-21}$ rather than from chemicals derived from petroleum is even more intriguing, since ionic liquids are commonly regarded as green solvents.

We recently reported the synthesis of a novel class of pyrrolidinium cations for the obtainment of chiral ionic compounds based on L-tartaric acid (compounds 1-12). ${ }^{22}$ Two out of the twelve ionic compounds 1-12 synthesized (namely 8 and 12) were liquid at room temperature, and 4 showed a low melting point $\left(50-53{ }^{\circ} \mathrm{C}\right)$. Therefore, the bis(triflyl)amide anion proved to be the best for lowering the melting point of the resulting salts. Moreover, also disrupting the $C_{2}$-symmetry of the molecule (compound 12 vs 8) resulted an effective way for obtaining lower melting point salts. Thus we speculated that $(S)$-malic acid, that does not have 
the $C_{2}$ symmetry, could be a promising starting material for the synthesis of novel pyrrolidinium cations.

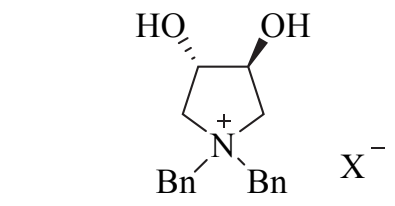

$\mathrm{X}=\mathrm{Br}$
$\mathrm{X}=\mathrm{BF}_{4}$
$\mathrm{X}=\mathrm{PF}_{6}$
$\mathrm{X}=\mathrm{NTf}_{2}$
(1)

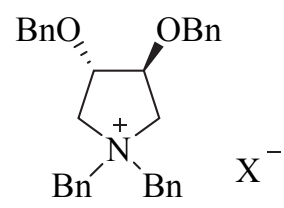

(5)

(6)

(7)

(8)

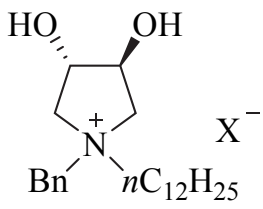

(9)

(10)

(11)

(12)

We present in this work the synthesis of six novel ionic salts from natural $(S)$-malic acid, two of which turned out to be liquid at room temperature. While malic and tartaric acids have already been reported as anions of some chiral ionic liquids, ${ }^{23-25}$ the use of $(S)$-malic acid for the synthesis of chiral ionic liquids based on a chiral cation is unprecedented, to the best of our knowledge.

\section{Results and Discussion}

Our strategy started from low cost $(S)$-malic acid (13, Scheme 1). Since direct condensation with benzylamine at reflux followed by reduction with $\mathrm{LiAlH}_{4}$ had been reported to occur with partial epimerization at $\mathrm{C} 3,{ }^{26}$ we followed a much milder procedure that implied prior activation with acetyl chloride, reaction with benzylamine at $20-25{ }^{\circ} \mathrm{C}$ and then further treatment with acetyl chloride. $^{27}$ This afforded compound $\mathbf{1 4}$ in $90 \%$ yield. The subsequent reduction with lithium aluminum hydride gave (3S)-1-benzyl-3-pyrrolidinol (15) in $87 \%$ yield following a slight modification of the published procedure during the quench of the reaction (Scheme 1).

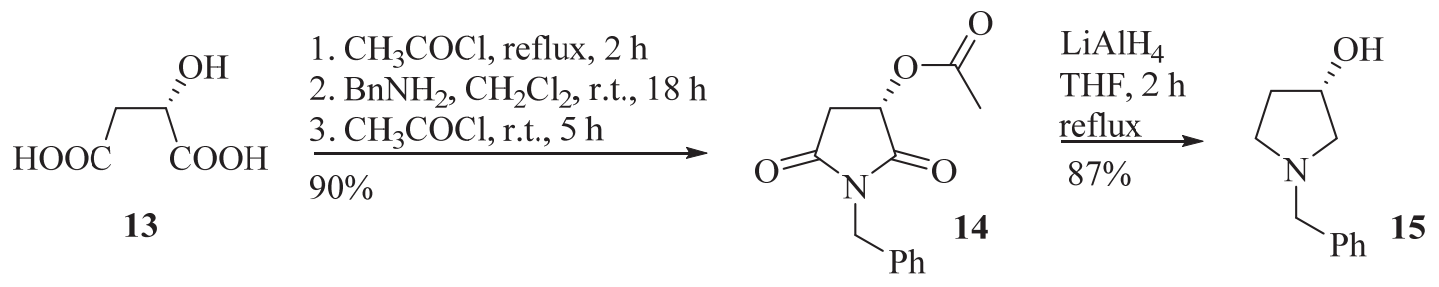

Scheme 1. Preparation of the 3(S)-1-benzyl-3-pyrrolidinol (15) from $(S)$-malic acid (13).

Quaternization of pyrrolidinol 15 was achieved using a slight excess of benzyl bromide in acetonitrile at $90{ }^{\circ} \mathrm{C}$ (Scheme 2). The reaction was performed either with traditional and microwave (MW) heating, obtaining comparable yields (68\% and $71 \%$ yields, respectively) but lower reaction times with the MW heating (10 min $v s 1 \mathrm{~h}$ ) on a gram scale of $\mathbf{1 5 .}$ 
16

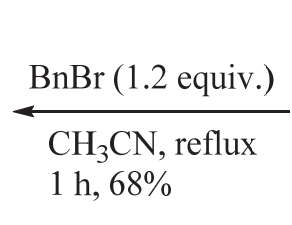

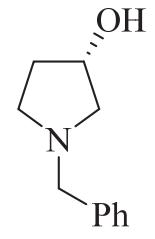

15

$\mathrm{OH}$

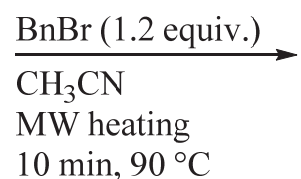

$150 \mathrm{~W}, 71 \%$

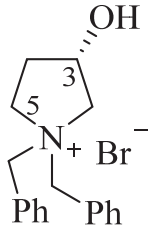

16

Scheme 2. Synthesis of the pyrrolidinium salt $\mathbf{1 6}$.

The bromide salt 16 was purified by crystallization from ethyl acetate and diethyl ether obtaining a solid compound with mp 149-150 ${ }^{\circ} \mathrm{C}$. Compound 16 was soluble in acetonitrile, $\mathrm{MeOH}$ and water ${ }^{28}$ while it did not dissolve in acetone, diethyl ether and ethyl acetate at room temperature. Anion exchange was attempted by dissolving in water or suspending in acetone, respectively, the solid material $\mathbf{1 6}$ in the presence of 1 equivalent of the appropriate salt at room temperature overnight (Table 1). The reaction in acetone did not occur, probably due to the low solubility of $\mathbf{1 6}$ in this solvent (entries 1 and 4, Table 1). Heating the mixture at reflux for $1 \mathrm{~h}$ gave no better results. Instead, the anion exchange reaction was successful using water as solvent. After overnight stirring, extraction with ethyl acetate afforded salts $\mathbf{1 7}$ and $\mathbf{1 8}$ in good to excellent yields (Table 1, entries 2 and 3). In the case of the bis(triflyl)amide salt 19, formation of some drops of an oil that separated from the aqueous phase was observed. Upon extraction with ethyl acetate, the pure ionic liquid $\mathbf{1 9}$ was isolated in 91\% yield (Table 1, entry 5) after removal of the solvent. Similarly to what observed for the pyrrolidinium compounds derived from L-tartaric acid, ${ }^{22}$ the bis(triflyl)amide anion was able to lower the melting point of the ionic material much more efficiently than the tetrafluoroborate or the hexafluorophosphate anions. Ionic liquid 19 was soluble in methanol, ethyl acetate and chloroform, ${ }^{28}$ and had an excellent thermal stability, showing no sign of decomposition upon heating at $120{ }^{\circ} \mathrm{C}$ for 15 hours. Ionic compound 17 , that is solid at r.t. with a mp $146-147{ }^{\circ} \mathrm{C}$, was soluble in water, ethyl acetate and acetone,$^{28}$ while 18 , that is solid at r.t. with a mp $151-152^{\circ} \mathrm{C}$, showed solubility in ethyl acetate and chloroform. ${ }^{28}$

An X-ray structure of compound $\mathbf{1 7}$ was collected after crystallization from a solution in acetone by slow addition of diisopropyl ether. Crystals of $\mathbf{1 7}$ (Figure 1) showed a N-B distance of $4.523 \AA$ within each molecule and no $\pi$-stacking between the aromatic rings were observed, nor $\mathrm{CH}-\pi$ interactions. 
Table 1. Anion exchange reaction. Synthesis of compounds 17-19

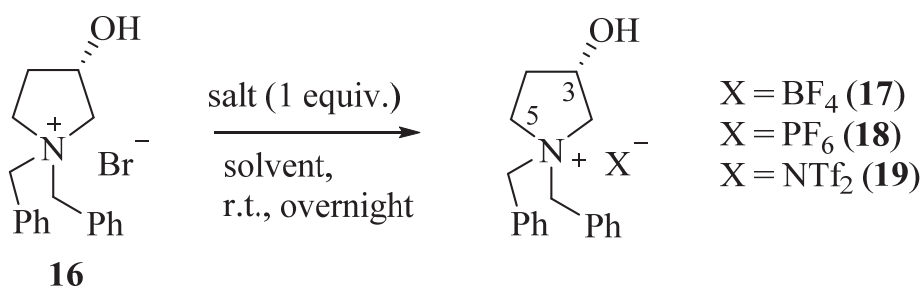

\begin{tabular}{cccccc}
\hline Entry & Salt & Solvent & Product & Yield (\%) & $\begin{array}{c}\text { State at r.t. } \\
\left(\mathrm{Mp}\left({ }^{\circ} \mathrm{C}\right)\right)^{\mathrm{a}}\end{array}$ \\
\hline 1 & $\mathrm{KBF}_{4}$ & acetone & - & - & - \\
2 & $\mathrm{KBF}_{4}$ & water & $\mathbf{1 7}$ & 66 & solid (146-147) \\
3 & $\mathrm{KPF}_{6}$ & water & $\mathbf{1 8}$ & 96 & solid (151-152) \\
4 & $\mathrm{LiNTf}_{2}$ & acetone & - & - & - \\
5 & $\mathrm{LiNTf}_{2}$ & water & $\mathbf{1 9}$ & 91 & liquid \\
\hline
\end{tabular}

${ }^{a} \mathrm{Mp}$ were given for those salts that are solid at room temperature.

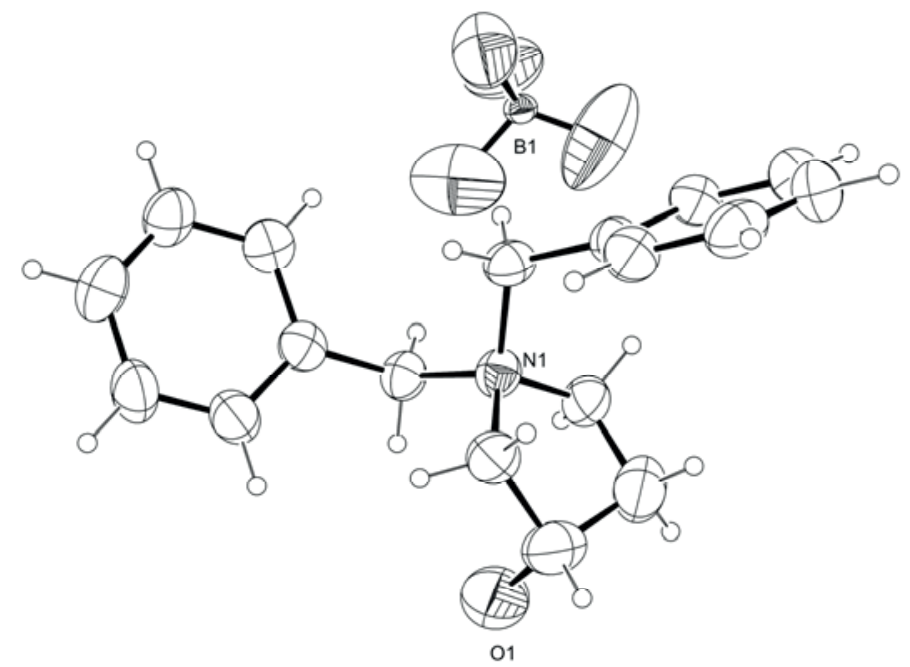

Figure 1. X-ray crystal structure of 17.

We then turned to investigate the possibility of introducing a different substituent on the nitrogen atom. (3S)-1-benzyl-3-pyrrolidinol (15) was then subjected to catalytic hydrogenolysis providing pyrrolidinol 20 in quantitative yield (Scheme 3). ${ }^{27}$ Subsequent alkylation with 1.2 equivalents of $n$-butyl bromide in $\mathrm{CH}_{3} \mathrm{CN}$ at room temperature in the presence of $\mathrm{K}_{2} \mathrm{CO}_{3}$ gave (3S)-1-butyl-3-pyrrolidinol (21) in 69\% yield. Quaternization of 21 using 1.5 equivalents of $\mathrm{BuBr}$ in acetonitrile at reflux for $4 \mathrm{~h}$ afforded the salt $\mathbf{2 2}$ in $73 \%$ yield, while the reaction under MW heating gave a complex mixture of products. 


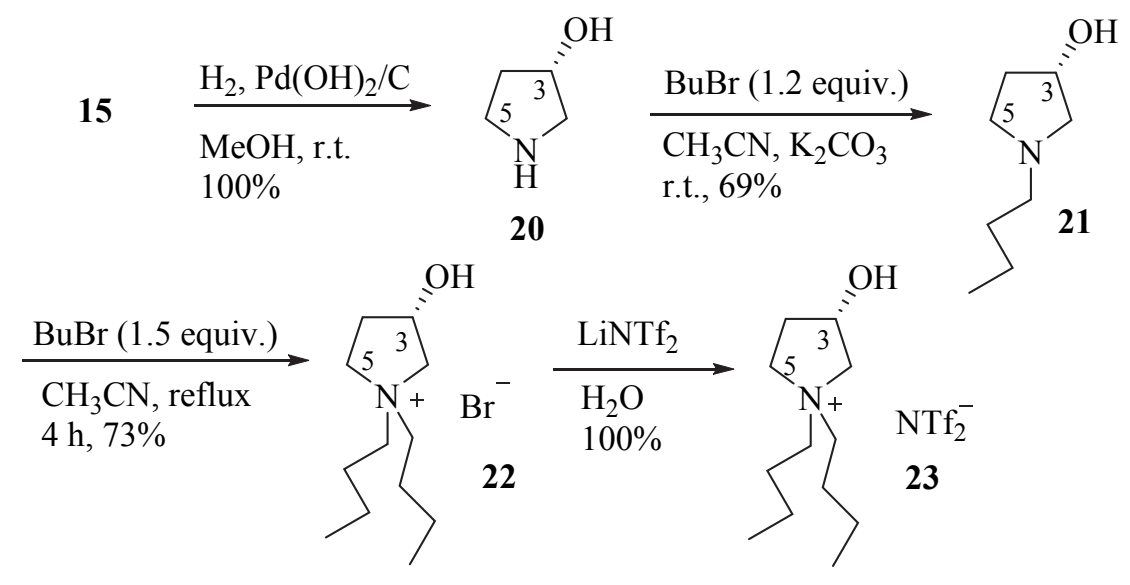

Scheme 3. Synthesis of ionic liquid 23.

Compound 22 was obtained as a highly hygroscopic white solid, that dissolved immediately in the presence of traces of water. Anion exchange was achieved by reaction of 1 equivalent of LiNTf $_{2}$ in water, since this solvent had allowed the best results for the anion exchange of bromide salt 16. Compound 23 was isolated in quantitative yield after extraction with AcOEt and was liquid at room temperature. Ionic liquid $\mathbf{2 3}$ was soluble in water, ethyl acetate and chloroform, ${ }^{28}$ and had a good thermal stability, showing no appreciable decomposition upon heating at $120^{\circ} \mathrm{C}$ for 15 hours.

\section{Conclusions}

A facile and straightforward synthesis of six novel ionic compounds having a chiral pyrrolidinium cation derived from $(S)$-malic acid and several different anions is reported. Two of them were liquid at room temperature, and therefore can be applied as novel reaction media for asymmetric organic reactions or other enantioselective applications.

\section{Experimental Section}

General. Commercial reagents were used as received. Rf values refer to thin-layer chromatography (TLC) on $0.25-\mathrm{mm}$ silica gel plates (Merck F254). Melting points were determined on a RCH Kofler apparatus or on a Buchi 510 apparatus and are uncorrected. ${ }^{1} \mathrm{H}$ and ${ }^{13} \mathrm{C}-\mathrm{NMR}$ spectra were recorded on Varian Gemini $\left({ }^{1} \mathrm{H}, 200 \mathrm{MHz}\right)$ and Varian MERCURY plus $\left({ }^{1} \mathrm{H}, 400 \mathrm{MHz}\right)$ instruments; the chemical shifts for ${ }^{1} \mathrm{H}$ and ${ }^{13} \mathrm{C}-\mathrm{NMR}$ spectra are given in ppm relative to TMS at $25^{\circ} \mathrm{C}$, and coupling constants are given in Hz. IR spectra were recorded with a BX FT-IR Perkin-Elmer System spectrophotometer. Mass spectra were recorded with a QMD 1000 Carlo Erba instrument $(\mathrm{EI}, 70 \mathrm{eV}$ ) after direct inlet (relative percentages are given in 
brackets). Elemental analyses were performed with a Perkin-Elmer $240 \mathrm{C}$ instrument. Small scale microwave-assisted synthesis was carried out in a Microwave apparatus for synthesis CEM Discover with an open reaction vessel and external surface sensor. X-ray data for structure resolution were collected with a Goniometer Oxford Diffraction KM4 Xcalibur2, using $\mathrm{Cu} / \mathrm{K} \alpha$ radiation $(40 \mathrm{~mA} /-40 \mathrm{KV})$ at room temperature .

(3S)-3-Acetyloxy-1-benzyl-2,5-pyrrolidinedione (14). ${ }^{27}$ A mixture of $(S)$-(-)-malic acid (6.74 $\mathrm{g}, 50.3 \mathrm{mmol})$ and acetyl chloride $(20 \mathrm{~mL}, 281.5 \mathrm{mmol}, 5.6$ equiv.) was heated at reflux for $2 \mathrm{~h}$. The solvent was then removed under reduced pressure, and the residue was dissolved in dichloromethane $(100 \mathrm{~mL})$. Benzylamine $(20 \mathrm{~mL}, 180.9 \mathrm{mmol}, 3.6$ equiv.) was added slowly in an ice bath under vigorous stirring. The reaction mixture was stirred at room temperature for 18 h. Acetyl chloride $(20 \mathrm{~mL}, 281.5 \mathrm{mmol}, 5.6$ equiv.) was then added and the mixture was stirred at reflux temperature for $5 \mathrm{~h}$. A 3:1 mixture of AcOEt/petroleum ether was added to the crude mixture, and the resulting solid was filtered on Buchner. The filtered solution was evaporated to dryness, and the orange oil was purified by flash column chromatography on silica gel using $\mathrm{AcOEt} /$ petroleum ether 3:1 as eluent, to give $\mathbf{1 4}$ as an orange oil ( $\mathrm{Rf} 0.81,11.28 \mathrm{~g}, 45.6 \mathrm{mmol}$, 90\%). The ${ }^{1} \mathrm{H}-\mathrm{NMR}$ matched with that previously reported. ${ }^{27}{ }^{1} \mathrm{H}-\mathrm{NMR}\left(200 \mathrm{MHz}, \mathrm{CDCl}_{3}\right): \delta$ 7.40-7.26 (m, 5H, H-Ar), 5.42 (dd, J 8.8, 4.8 Hz, 1H, H-3), 4.80-4.60 (m, 2H, $\mathrm{CH}_{2} \mathrm{Ph}$ ), 3.14 (dd, $J 18.3,8.8 \mathrm{~Hz}, 1 \mathrm{H}, \mathrm{Ha}-4), 2.64$ (dd, $J 18.3,4.8 \mathrm{~Hz}, 1 \mathrm{H}, \mathrm{Hb}-4), 2.13$ (s, 3H, $\mathrm{CH}_{3}$ ).

(3S)-1-Benzylpyrrolidin-3-ol (15). ${ }^{27}$ To a suspension of lithium aluminum hydride $(2.59 \mathrm{~g}$, $68.3 \mathrm{mmol})$ in $50 \mathrm{~mL}$ of dry THF a solution of $14(5.45 \mathrm{~g}, 22.04 \mathrm{mmol})$ in $40 \mathrm{~mL}$ of dry THF was added dropwise under vigorous stirring. The reaction mixture was heated under reflux for 2 h. A TLC control $\left(\mathrm{CH}_{2} \mathrm{Cl}_{2}: \mathrm{MeOH}: \mathrm{NH}_{3}\right.$ 150:16:1) showed the appearance of a new product and the disappearance of the starting material. A saturated solution of $\mathrm{Na}_{2} \mathrm{SO}_{4}$ was then added, and the resulting salts were thoroughly washed with $\mathrm{CH}_{2} \mathrm{Cl}_{2}$. Evaporation under reduced pressure gave 15 (Rf 0.57, $3.88 \mathrm{~g}, 21.9 \mathrm{mmol}, 87 \%$ ) as an oil sufficiently pure to be used for the next step. ${ }^{1} \mathrm{H}-\mathrm{NMR}\left(400 \mathrm{MHz}, \mathrm{CDCl}_{3}\right.$ ): $\delta$ 7.36-7.22 (m, 5H, H-Ar), 4.32 (ddt, J 7.4, 5.0, 2.1 Hz, 1H, Ha-3), $3.63\left(\mathrm{~s}, 2 \mathrm{H}, \mathrm{CH}_{2} \mathrm{Ph}\right), 2.85$ (td, $\left.J 8.7,5.1 \mathrm{~Hz}, 1 \mathrm{H}, \mathrm{Ha}-5\right), 2.66$ (dd, $\left.J 10.2,2.1 \mathrm{~Hz}, 1 \mathrm{H}, \mathrm{Ha}-2\right), 2.63-$ 2.52 (br, OH), 2.55 (dd, $J=10.2,5.3 \mathrm{~Hz}, 1 \mathrm{H}, \mathrm{Hb}-2), 2.32$ (td, $J$ 8.9, $6.4 \mathrm{~Hz}, 1 \mathrm{H}, \mathrm{Hb}-5), 2.23-2.14$ (m, 1H, Ha-4), 1.80-1.69 (m, 1H, Hb-4). ${ }^{13} \mathrm{C}-\mathrm{NMR}\left(50 \mathrm{MHz}, \mathrm{CDCl}_{3}\right): \delta 138.4(\mathrm{~s}, \mathrm{C}-\mathrm{Ar}), 128.7$ (d, 2C, C-Ar), 128.1 (d, 2C, C-Ar), 126.9 (s, C-Ar), 71.3 (d, C-3), 62.9 (t, C-2), 60.2 (t, $\mathrm{CH}_{2} \mathrm{Ph}$ ), 52.4 (t, C-5), 35.0 (t, C-4). IR $\left(\mathrm{CH}_{2} \mathrm{Cl}_{2}\right): 3602,2964,1453,1124,1074 \mathrm{~cm}^{-1}$. MS: $m / z(\%) 177$ $\left(\mathrm{M}^{+}, 48\right), 132$ (38), 100 (22), 91 (100), 65 (27). Anal. Calcd. For $\mathrm{C}_{11} \mathrm{H}_{15} \mathrm{NO}$ (177.24): C, 74.54; H, 8.53; N, 7.90. Found: C, 74.53; H, 8.13; N, 7.58.

(3S)-1,1-Dibenzyl-3-hydroxypyrrolidinium bromide (16). Compound 15 (1.29 g, 6.9 mmol) was dissolved in $35 \mathrm{~mL}$ of $\mathrm{CH}_{3} \mathrm{CN}$ and benzyl bromide ( $8.3 \mathrm{mmol}, 1.2$ equiv.) was added. The reaction was heated in the $\mathrm{MW}$ apparatus for 10 minutes at $90{ }^{\circ} \mathrm{C}$ and $150 \mathrm{~W}$. A TLC control $\left(\mathrm{CH}_{2} \mathrm{Cl}_{2}: \mathrm{MeOH}: \mathrm{NH}_{3}\right.$ 150:16:1) showed the disappearance of the starting material. A 1:1 mixture of AcOEt/diethyl ether was added to the reaction mixture, and the resulting salts were separated by decantation. The remaining solution was evaporated under reduced pressure and the residue 
was dissolved in the minimum amount of $\mathrm{CH}_{3} \mathrm{CN}$, then a 1:1 mixture of AcOEt/diethyl ether was added and further salts were collected. The combined salts were thoroughly washed with acetone, affording pure $16(1.714 \mathrm{~g}, 4.92 \mathrm{mmol}, 71 \%)$ as a white solid, mp $150-151{ }^{\circ} \mathrm{C}$. $[\alpha]_{\mathrm{D}}{ }^{27}$ +9.7 (c 0.93, MeOH). ${ }^{1} \mathrm{H}-\mathrm{NMR}\left(400 \mathrm{MHz}, \mathrm{CD}_{3} \mathrm{OD}\right): \delta$ 7.73-7.71 (m, 2H, H-Ar), 7.60-7.47 (m, 8H, H-Ar), 4.91 (d, J 13.1 Hz, 1H, $\left.\mathrm{CH}_{2} \mathrm{Ph}\right), 4.86$ (d, J 13.1 Hz, 1H, $\left.\mathrm{CH}_{2} \mathrm{Ph}\right), 4.64$ (d, J $12.9 \mathrm{~Hz}$, $\left.1 \mathrm{H}, \mathrm{CH}_{2} \mathrm{Ph}\right), 4.51\left(\mathrm{~d}, J 13.1 \mathrm{~Hz}, 1 \mathrm{H}, \mathrm{CH}_{2} \mathrm{Ph}\right), 4.56-4.50(\mathrm{~m}, 1 \mathrm{H}, \mathrm{H}-3), 3.82$ (dt, $J 12.3,7.4 \mathrm{~Hz}$, 1H, Ha-5), 3.65-3.57 (m, 3H, Hb-5, Ha-2, Hb-2), 2.24-2.15 (m, 1H, Ha-4), 2.11-2.01 (m, 1H, Hb-4). ${ }^{13} \mathrm{C}-\mathrm{NMR}$ (50 MHz, CD $\mathrm{CD}_{3}$ ): $\delta 133.1$ (s, C-Ar), 133.0 (s, C-Ar), 130.4 (d, 2C, C-Ar), 130.3 (d, 2C, C-Ar), 129.0 (d, 2C, C-Ar), 128.9 (d, 2C, C-Ar), 128.1 (d, C-Ar), 127.6 (d, C-Ar), 68.3 (d, C-3), 66.8 (t, $\mathrm{CH}_{2} \mathrm{Ph}$ ), 64.5 (t, C-2), 64.1 (t, $\left.\mathrm{CH}_{2} \mathrm{Ph}\right), 58.1$ (t, C-5), 32.5 (t, C-4). IR (KBr): 3254, 3027, 2992, 2943, 1456, $1109 \mathrm{~cm}^{-1}$. MS: $m / z(\%) 268\left(\mathrm{M}^{+}-\mathrm{Br}, 0.2\right), 177\left(\mathrm{M}^{+}-91\right.$, 15), 132 (13), 100 (8), 91 (100), 65 (23). Anal. Calcd. For $\mathrm{C}_{18} \mathrm{H}_{22} \mathrm{BrNO}$ (348.28): C, 62.07; H, 6.37 ; N, 4.02. Found: C, 61.68; H, 6.00; N, 4.04.

(3S)-1,1-Dibenzyl-3-hydroxypyrrolidinium tetrafluoroborate (17). To a solution of $16(0.214$ $\mathrm{g}, 0.61 \mathrm{mmol})$ in $5 \mathrm{~mL}$ of water $\mathrm{KBF}_{4}(0.077 \mathrm{~g}, 0.61 \mathrm{mmol})$ was added. The mixture was left stirring at room temperature overnight, then it was extracted with AcOEt $(3 \mathrm{X} 5 \mathrm{~mL})$. After addition of dry $\mathrm{Na}_{2} \mathrm{SO}_{4}$ and decantation the organic phase was concentrated under reduced pressure to give $17(0.143 \mathrm{~g}, 0.40 \mathrm{mmol}, 66 \%)$ as a white solid, that was recrystallized by acetone/diisopropropylether. $\mathrm{Mp} 146-147{ }^{\circ} \mathrm{C}$ ( $\mathrm{Rf} 0.46$ with eluent $\left.\mathrm{CH}_{2} \mathrm{Cl}_{2} / \mathrm{MeOH} 10: 1\right)$. $[\alpha]_{\mathrm{D}}{ }^{27}$ +8.4 (c 0.79, acetone). ${ }^{1} \mathrm{H}-\mathrm{NMR}\left(400 \mathrm{MHz}\right.$, acetone- $\left.\mathrm{d}_{6}\right): \delta$ 7.84-7.81 (m, 2H, H-Ar), 7.66-7.48 (m, 8H, H-Ar), 5.07 (d, J 13.5 Hz, 1H, $\left.\mathrm{CH}_{2} \mathrm{Ph}\right), 5.02$ (d, J 13.1 Hz, 1H, $\left.\mathrm{CH}_{2} \mathrm{Ph}\right), 4.82$ (d, J 13.1 $\mathrm{Hz}, 1 \mathrm{H}, \mathrm{CH}_{2} \mathrm{Ph}$ ), 4.68 (d, J 13.1 Hz, 1H, $\left.\mathrm{CH}_{2} \mathrm{Ph}\right), 4.74-4.70(\mathrm{~m}, 1 \mathrm{H}, \mathrm{H}-3), 4.02-3.96$ (m, 1H, Ha5), 3.83-3.70 (m, 3H, Hb-5, Ha-2, Hb-2), 2.36-2.33 (m, 1H, Ha-4), 2.22-2.20 (m, 1H, Hb-4). ${ }^{13} \mathrm{C}-$ NMR (50 MHz, acetone- $\mathrm{d}_{6}$ ): $\delta 133.6$ (d, 2C, C-Ar), 133.5 (d, 2C, C-Ar), 130.5 (d, C-Ar), 130.4 (d, C-Ar), 129.2 (d, 4C, C-Ar), 128.6 (s, C-Ar), 128.1 (s, C-Ar), 68.5 (d, C-3), 66.4 (t, $\mathrm{CH}_{2} \mathrm{Ph}$ ), 64.4 (t, C-2), 63.7 (t, $\mathrm{CH}_{2} \mathrm{Ph}$ ), 58.1 (t, C-5), 32.4 (t, C-4). ${ }^{19} \mathrm{~F}-\mathrm{NMR}\left(188 \mathrm{MHz}, \mathrm{CDCl}_{3}\right.$ ): $\delta-149.8$ $\left(\mathrm{s}, \mathrm{BF}_{4}\right) . \mathrm{IR}(\mathrm{KBr}): 3407,3255,2355,2336,1457,1107,1065 \mathrm{~cm}^{-1}$.

MS: $m / z(\%) 268\left(\mathrm{M}^{+}-\mathrm{BF}_{4}, 2\right), 210$ (34), 120 (9), 91 (100), 65 (11). Anal. Calcd. For $\mathrm{C}_{18} \mathrm{H}_{22} \mathrm{BF}_{4} \mathrm{NO}$ (355.18): C, 60.87; H, 6.24; N, 3.94. Found: C, 60.49; H, 6.32; N, 3.87.

Crystal data for 17. $\mathrm{C}_{18} \mathrm{H}_{22} \mathrm{NOBF}_{4}, \mathrm{M}=355.18$, Hexagonal, space group $\mathrm{P} 3_{2}, a=11.082(1)$, $b=11.082(1), c=12.465(1) \AA, \mathrm{V}=1325.7(2) \AA^{3}, \mathrm{Z}=3 \mathrm{D}_{\mathrm{c}}=1.335, \mu=0.938 \mathrm{~mm}^{-1}, \mathrm{~F}(000)=558$.

2535 reflections were collected with a $4.61<\theta<63.71$ range with a completeness to theta $91.5 \%$; 1901 were unique, the parameters were 227 and the final $\mathrm{R}$ index was 0.0539 for reflections having $\mathrm{I}>2 \sigma \mathrm{I}$, and 0.0910 for all data. Hydrogen atoms were all assigned in calculated positions. The X-ray CIF file has been deposited at the Cambridge Crystallographic Data Center and allocated with the deposition number CCDC 934303.

Copies of the data can be obtained, free of charge, from CCDC, 12 Union Road, Cambridge, CB2 1EZ UK (internet://www.ccdc.cam.ac.uk).

(3S)-1,1-Dibenzyl-3-hydroxypyrrolidinium hexafluorophosphate (18). To a solution of 16 $(0.198 \mathrm{~g}, 0.57 \mathrm{mmol})$ in $4 \mathrm{~mL}$ of water $\mathrm{KPF}_{6}(0.105 \mathrm{~g}, 0.57 \mathrm{mmol})$ was added. The mixture was 
left stirring at room temperature overnight, then it was extracted with AcOEt $(3 \mathrm{X} 5 \mathrm{~mL})$. After addition of dry $\mathrm{Na}_{2} \mathrm{SO}_{4}$ and decantation the organic phase was concentrated under reduced pressure to give $18(0.26 \mathrm{~g}, 0.55 \mathrm{mmol}, 96 \%)$ as a white solid, mp 151-152 ${ }^{\circ} \mathrm{C}(\mathrm{Rf} 0.54$ with eluent $\left.\mathrm{CH}_{2} \mathrm{Cl}_{2} / \mathrm{MeOH} 10: 1\right)$. $[\alpha]_{\mathrm{D}}{ }^{24}+7.2$ (c 0.74, MeOH). ${ }^{1} \mathrm{H}-\mathrm{NMR}$ (400 MHz, acetone- $\mathrm{d}_{6}$ ): $\delta$ 7.83-7.80 (m, 2H, H-Ar), 7.65-7.50 (m, 8H, H-Ar), 5.08 (d, $\left.J 13.3 \mathrm{~Hz}, 1 \mathrm{H}, \mathrm{CH}_{2} \mathrm{Ph}\right), 5.00$ (d, $J$ $\left.13.1 \mathrm{~Hz}, 1 \mathrm{H}, \mathrm{CH}_{2} \mathrm{Ph}\right), 4.81\left(\mathrm{~d}, J 13.1 \mathrm{~Hz}, 1 \mathrm{H}, \mathrm{CH}_{2} \mathrm{Ph}\right), 4.70\left(\mathrm{~d}, J 12.9 \mathrm{~Hz}, 1 \mathrm{H}, \mathrm{CH}_{2} \mathrm{Ph}\right), 4.79-4.74$ (m, 1H, H-3), 4.03-3.96 (m, 1H, Ha-5), 3.83-3.73 (m, 3H, Hb-5, Ha-2, Hb-2), 2.48-2.39 (m, 1H, Ha-4), 2.28-2.21 (m, 1H, Hb-4). ${ }^{13} \mathrm{C}-\mathrm{NMR}\left(50 \mathrm{MHz}\right.$, acetone- $\left.\mathrm{d}_{6}\right): \delta 133.4(\mathrm{~d}, 2 \mathrm{C}, \mathrm{C}-\mathrm{Ar}), 133.3$ (d, 2C, C-Ar), 130.6 (d, C-Ar), 130.5 (d, C-Ar), 129.2 (d, 4C, C-Ar), 128.3 (s, C -Ar), 127.8 (s, C-Ar), 68.6 (d, C-3), 66.7 (t, $\left.\mathrm{CH}_{2} \mathrm{Ph}\right), 64.5$ (t, C-2), 64.0 (t, $\left.\mathrm{CH}_{2} \mathrm{Ph}\right), 58.2$ (t, C-5), 32.7 (t, C4). ${ }^{19} \mathrm{~F}-\mathrm{NMR}\left(188 \mathrm{MHz}, \mathrm{CDCl}_{3}\right): \delta-71.6\left(\mathrm{~d}, J 714.4 \mathrm{~Hz}, \mathrm{PF}_{6}\right) . \mathrm{IR}(\mathrm{KBr}): 3587,3066,2962,2933$, 1457, 1112, $1065 \mathrm{~cm}^{-1}$. MS: $m / z$ (\%) 159 (60), 91 (100), 65 (17). Anal. Calcd. For $\mathrm{C}_{18} \mathrm{H}_{22} \mathrm{~F}_{6} \mathrm{NOP}$ (413.13): C, 52.30; H, 5.36; N, 3.39. Found: C, 52.28; H, 5.49, N, 3.25.

(3S)-1,1-Dibenzyl-3-hydroxypyrrolidinium bis(triflyl)amide (19). To a solution of 16 (0.214 $\mathrm{g}, 0.61 \mathrm{mmol})$ in $4 \mathrm{~mL}$ of water $\operatorname{LiNTf}_{2}(0.176 \mathrm{~g}, 0.61 \mathrm{mmol})$ was added. The mixture was left stirring at room temperature overnight, and an oil separated from the aqueous phase. The mixture was then extracted with AcOEt $(3 \mathrm{X} 5 \mathrm{~mL})$. After addition of dry $\mathrm{Na}_{2} \mathrm{SO}_{4}$ and decantation the organic phase was concentrated under reduced pressure to give $19(0.306 \mathrm{~g}, 0.56 \mathrm{mmol}, 96 \%)$ as a viscous yellow oil (Rf 0.46 with eluent $\left.\mathrm{CH}_{2} \mathrm{Cl}_{2} / \mathrm{MeOH} 10: 1\right)$. $[\alpha]_{\mathrm{D}}{ }^{24}+6.8(c 1.16, \mathrm{MeOH}) .{ }^{1} \mathrm{H}-$ NMR (400 MHz, CD 3 OD): $\delta$ 7.71-7.66 (m, 2H, H-Ar), 7.61-7.49 (m, 8H, H-Ar), 4.87 (d, J 12.9 $\left.\mathrm{Hz}, 1 \mathrm{H}, \mathrm{CH}_{2} \mathrm{Ph}\right), 4.80\left(\mathrm{~d}, J=13.1 \mathrm{~Hz}, 1 \mathrm{H}, \mathrm{CH}_{2} \mathrm{Ph}\right), 4.57\left(\mathrm{~d}, J 12.9 \mathrm{~Hz}, 1 \mathrm{H}, \mathrm{CH}_{2} \mathrm{Ph}\right), 4.46(\mathrm{~d}, J$ $\left.12.9 \mathrm{~Hz}, 1 \mathrm{H}, \mathrm{CH}_{2} \mathrm{Ph}\right), 4.54-4.49$ (m, 1H, H-3), 3.80 (td, J 7.4, $\left.12.3 \mathrm{~Hz}, 1 \mathrm{H}, \mathrm{Ha}-5\right), 3.63-3.54$ (m, $3 \mathrm{H}, \mathrm{Hb}-5, \mathrm{Ha}-2, \mathrm{Hb}-2), 2.23-2.14$ (m, 1H, Ha-4), 2.11-2.04 (m, 1H, Hb-4). ${ }^{13} \mathrm{C}-\mathrm{NMR}(50 \mathrm{MHz}$, $\mathrm{CD}_{3} \mathrm{OD}$ ): $\delta 134.3$ (d, 2C, C-Ar), 134.2 (d, 2C, C-Ar), 131.7 (d, C-Ar), 131.6 (d, C-Ar), 130.3 (d, 4C, C-Ar), 129.2 (s, C-Ar), 128.7 (s, C-Ar), 69.5 (d, C-3), 68.2 (t, $\mathrm{CH}_{2} \mathrm{Ph}$ ), 65.7 (t, C-2), 65.5 (t, $\left.\mathrm{CH}_{2} \mathrm{Ph}\right), 59.3$ (t, C-5), 33.7 (t, C-4). ${ }^{19} \mathrm{~F}-\mathrm{NMR}\left(188 \mathrm{MHz}, \mathrm{CDCl}_{3}\right): \delta$-78.7 (s, $\left.\mathrm{CF}_{3}\right) . \mathrm{IR}\left(\mathrm{CH}_{2} \mathrm{Cl}_{2}\right)$ : 3502, 3053, 2981, 2305, 1421, $1056 \mathrm{~cm}^{-1}$. MS: $m / z(\%) 268\left(\mathrm{M}^{+}-\mathrm{NTf}_{2}, 12\right), 178\left(\mathrm{M}^{+}-90,23\right), 133$ (14), 91 (100), 69 (85), 65 (27). Anal. Calcd. For $\mathrm{C}_{20} \mathrm{H}_{22} \mathrm{~F}_{6} \mathrm{~N}_{2} \mathrm{O}_{5} \mathrm{~S}_{2}(548.52)$ : C, 43.79; H, 4.04; N, 5.11. Found: C, 43.48; H, 3.99; N, 4.89.

(3S)-Pyrrolidin-3-ol (20). ${ }^{27}$ To a solution of 15 (1.59 g, $\left.8.97 \mathrm{mmol}\right)$ in $23 \mathrm{~mL}$ of MeOH 20\% $\mathrm{Pd}(\mathrm{OH})_{2} / \mathrm{C}$ was added $(0.803 \mathrm{~g})$. The mixture was left stirring under $\mathrm{H}_{2}$ atmosphere (balloon) overnight, and then filtered through Celite. The filtrate was evaporated under reduced pressure to give 20 as a yellow oil $(0.76 \mathrm{~g}, 8.72 \mathrm{mmol})$ in quantitative yield, enough pure to be used for the next step. ${ }^{1} \mathrm{H}-\mathrm{NMR}\left(200 \mathrm{MHz}, \mathrm{CDCl}_{3}\right.$ ): $\delta$ 4.40-4.35 (m, 1H, H-3), 3.18-2.76 (m, 6H, Ha-2, Hb-2, Ha-5, Hb-5, NH, OH), 2.05-1.85 (m, 1H, Ha-4), 1.77-1.64 (m, 1H, Hb-4).

(3S)-1-Butylpyrrolidin-3-ol (21). To a solution of $20(0.782 \mathrm{~g}, 8.97 \mathrm{mmol})$ in $21 \mathrm{~mL}$ of $\mathrm{CH}_{3} \mathrm{CN}$ $\mathrm{K}_{2} \mathrm{CO}_{3}$ (3.72 g, 26.92 mmol, 3 equiv.) and butyl bromide (1.2 mL, $11.17 \mathrm{mmol}, 1.2$ equiv.) were added. The mixture was left stirring at room temperature overnight. A TLC control showed the disappearance of the starting material. The mixture was evaporated to dryness and the reside was dissolved in $25 \mathrm{~mL}$ of water. After extraction with AcOEt $(3 \mathrm{X} 10 \mathrm{~mL})$, the combined organic 
phases were treated with dry $\mathrm{Na}_{2} \mathrm{SO}_{4}$. Filtration and evaporation of the solvent afforded $\mathbf{2 1}$ as a yellow oil ( $0.892 \mathrm{~g}, 6.22 \mathrm{mmol}, 69 \%)$, enough pure to be used for the next step. ${ }^{1} \mathrm{H}-\mathrm{NMR}$ (400 MHz, $\mathrm{CDCl}_{3}$ ): $\delta$ 4.33-4.29 (dddd, $J$ 7.6, $5.3 \mathrm{~Hz}, 1 \mathrm{H}, \mathrm{H}-3$ ), 2.85 (td, $J$ 8.6, $4.7 \mathrm{~Hz}, 1 \mathrm{H}, \mathrm{Ha}-5$ ), 2.66 (dd, $J=10.2,2.0 \mathrm{~Hz}, 1 \mathrm{H}, \mathrm{Ha}-2), 2.48$ (dd, $J=10.2,5.5 \mathrm{~Hz}, 1 \mathrm{H}, \mathrm{Hb}-2), 2.43-2.39\left(\mathrm{~m}, 2 \mathrm{H}, \mathrm{CH}_{2} \mathrm{~N}\right.$ ), 2.24 (td, $J$ 8.8, $6.2 \mathrm{~Hz}, 1 \mathrm{H}, \mathrm{Hb}-5), 2.20-2.13$ (m, 1H, Ha-4), 1.75-1.67 (m, 1H, Hb-4), 1.51-1.43 (m, 2H, $\left.\mathrm{CH}_{2}\right), 1.37-1.28\left(\mathrm{~m}, 2 \mathrm{H}, \mathrm{CH}_{2}\right), 0.90\left(\mathrm{t}, J 7.3 \mathrm{~Hz}, 3 \mathrm{H}, \mathrm{CH}_{3}\right) .{ }^{13} \mathrm{C}-\mathrm{NMR}(50 \mathrm{MHz}$, $\left.\mathrm{CD}_{3} \mathrm{OD}\right): \delta 71.1(\mathrm{~d}, \mathrm{C}-3), 63.2(\mathrm{t}, \mathrm{C}-2), 56.1\left(\mathrm{t}, \mathrm{CH}_{2} \mathrm{~N}\right), 52.7(\mathrm{t}, \mathrm{C}-5), 34.9(\mathrm{t}, \mathrm{C}-4), 30.8\left(\mathrm{t}, \mathrm{CH}_{2}\right)$, $20.7\left(\mathrm{t}, \mathrm{CH}_{2}\right), 14.0\left(\mathrm{q}, \mathrm{CH}_{3}\right)$. IR $\left(\mathrm{CDCl}_{3}\right): 3606,2954,2927,1455,1143,1098 \mathrm{~cm}^{-1}$. MS: $\mathrm{m} / z(\%)$ $143\left(\mathrm{M}^{+}, 27\right), 100$ (100), 70 (19), 57 (58). Anal. Calcd. For $\mathrm{C}_{8} \mathrm{H}_{17} \mathrm{NO}$ (143.23): C, 67.09; H, 11.96 ; N, 9.78. Found: C, 67.32; H, 12.12; N, 10.02 .

(3S)-1,1-Dibutyl-3-hydroxypyrrolidinium bromide (22). To a solution of $21(0.232 \mathrm{~g}, 1.62$ mmol) in $7 \mathrm{~mL}$ of $\mathrm{CH}_{3} \mathrm{CN}$ butyl bromide $(0.26 \mathrm{~mL}, 2.43 \mathrm{mmol}, 1.5$ equiv.) was added. The mixture was heated at reflux temperature for $4 \mathrm{~h}$. A TLC control (eluent AcOEt/MeOH/NH$/ \mathrm{NHH}_{4}$ $8: 1: 1)$ showed the disappearance of the starting material. The mixture was evaporated under reduced pressure obtaining a viscous oil. The residue was dissolved in $1.3 \mathrm{~mL}$ of $\mathrm{CH}_{3} \mathrm{CN}$ and 3 $\mathrm{mL}$ of $\mathrm{Et}_{2} \mathrm{O}$ were added. The bromide 22 crystallized at $0{ }^{\circ} \mathrm{C}$, and the solid was washed with $\mathrm{Et}_{2} \mathrm{O}$. The ethereal phase was then evaporated to dryness and dissolved again in $1 \mathrm{~mL}$ of $\mathrm{CH}_{3} \mathrm{CN}$. By addition of further $4 \mathrm{~mL}$ of ether some more 22 crystallized. The combined solids (334 $\mathrm{mg}$, $1.19 \mathrm{mmol}, 73 \%)$ were completely characterized. $[\alpha]_{\mathrm{D}}{ }^{22}+1.9(c 0.84, \mathrm{MeOH}) .{ }^{1} \mathrm{H}-\mathrm{NMR}(400$ $\mathrm{MHz}, \mathrm{CD}_{3} \mathrm{OD}$ ): $\delta$ 4.66-4.60 (m, 1H, H-3), 3.84-3.77 (m, 1H, Ha-5), 3.67-3.40 (m, 5H, Ha-2, Hb2, $\mathrm{Hb}-5, \mathrm{CH}_{2} \mathrm{~N}$ ), 3.32-3.30 (m, $2 \mathrm{H}, \mathrm{CH}_{2} \mathrm{~N}$ ), 2.53-2.44 (m, 1H, Ha-4), 2.14-2.10 (m, $\left.1 \mathrm{H}, \mathrm{Hb}-4\right)$, 1.79-1.67 (m, 4H, CH $\left(50 \mathrm{MHz}, \mathrm{CD}_{3} \mathrm{OD}\right): \delta 71.0(\mathrm{~d}, \mathrm{C}-3), 69.1(\mathrm{t}, \mathrm{C}-2), 63.3(\mathrm{t}, \mathrm{C}-5), 61.6\left(\mathrm{t}, \mathrm{CH}_{2} \mathrm{~N}\right), 61.2\left(\mathrm{t}, \mathrm{CH}_{2} \mathrm{~N}\right)$, 32.6 (t, C-4), 25.5 (t, $\mathrm{CH}_{2}$ ), 25.4 (t, $\mathrm{CH}_{2}$ ), 19.7 (t, 2C, $\mathrm{CH}_{2}$ ), 13.7 (q, $\left.\mathrm{CH}_{3}\right), 13.6$ (q, $\mathrm{CH}_{3}$ ).

IR $\left(\mathrm{CDCl}_{3}\right): 3285,2959,2877,1466,1132,1060 \mathrm{~cm}^{-1} . \mathrm{MS}: \mathrm{m} / z(\%) 200\left(\mathrm{M}^{+}-\mathrm{Br}, 7\right), 142(46)$, 100 (100), 70 (7), 57 (72). Anal. Calcd. For $\mathrm{C}_{12} \mathrm{H}_{26} \mathrm{BrNO}$ (280.24): C, 51.43; H, 9.35; N, 5.00. Found: C, 51.00; H, 9.47; N, 4.89 .

(3S)-1,1-Dibutyl-3-hydroxypyrrolidinium bis(triflyl)amide (23). To a solution of 22 (94 $\mathrm{mg}$, $0.34 \mathrm{mmol})$ in $3 \mathrm{~mL}$ of water $\mathrm{LiNTf}_{2}(96.4 \mathrm{mg}, 0.34 \mathrm{mmol})$ was added. The mixture was left stirring at room temperature overnight. Extraction with AcOEt $(3 \mathrm{X} 5 \mathrm{~mL})$, treatment with $\mathrm{Na}_{2} \mathrm{SO}_{4}$, filtration and evaporation under reduced pressure quantitatively afforded $\mathbf{2 3}$ as a brown oil $(0.161 \mathrm{~g}, 0.34 \mathrm{mmol}, 100 \%)$. $[\alpha]_{\mathrm{D}}{ }^{22}+1.3$ (c 0.89 in $\left.\mathrm{MeOH}\right) .{ }^{1} \mathrm{H}-\mathrm{NMR}\left(400 \mathrm{MHz}, \mathrm{CD}_{3} \mathrm{OD}\right): \delta$ 4.64-4.58 (m, 1H, H-3). 3.83-3.76 (m, 1H, Ha-5), 3.62-3.39 (m, 5H, Ha-2, Hb-2, Hb-5, CH $\mathrm{CH}_{2}$ ), 3.33-3.26 (m, 2H, $\left.\mathrm{CH}_{2} \mathrm{~N}\right), 2.50-2.40(\mathrm{~m}, 1 \mathrm{H}, \mathrm{Ha}-4), 2.14-2.12(\mathrm{~m}, 1 \mathrm{H}, \mathrm{Hb}-4), 1.78-1.66(\mathrm{~m}, 4 \mathrm{H}$, $\left.\mathrm{CH}_{2}\right), 1.46-1.36\left(\mathrm{~m}, 4 \mathrm{H}, \mathrm{CH}_{2}\right), 1.01\left(\mathrm{t}, J 7.4 \mathrm{~Hz}, 6 \mathrm{H}, \mathrm{CH}_{3}\right) .{ }^{13} \mathrm{C}-\mathrm{NMR}\left(50 \mathrm{MHz}, \mathrm{CDCl}_{3}\right): \delta 70.9$ (d, C-3), 69.3 (t, C-2), 63.0 (t, C-5), $62.3\left(\mathrm{t}, \mathrm{CH}_{2} \mathrm{~N}\right), 61.7\left(\mathrm{t}, \mathrm{CH}_{2} \mathrm{~N}\right), 32.4$ (t, C-4), $25.2\left(\mathrm{t}, \mathrm{CH}_{2}\right)$, $25.1\left(\mathrm{t}, \mathrm{CH}_{2}\right), 19.5$ (t, 2C, $\left.\mathrm{CH}_{2}\right), 13.4\left(\mathrm{q}, \mathrm{CH}_{3}\right), 13.1$ (q, $\left.\mathrm{CH}_{3}\right) .{ }^{19} \mathrm{~F}-\mathrm{NMR}\left(188 \mathrm{MHz}, \mathrm{CDCl}_{3}\right): \delta-$ $79.1\left(\mathrm{~s}, \mathrm{CF}_{3}\right)$. IR $\left(\mathrm{CDCl}_{3}\right): 3515,2963,2936,2873,2257,1347,1198,1134,1058 \mathrm{~cm}^{-1} . \mathrm{MS}: \mathrm{m} / \mathrm{z}$ (\%) $200\left(\mathrm{M}^{+}-\mathrm{NTf}_{2}, 100\right), 142$ (18), 100 (26), 70 (8), 57 (8). Anal. Calcd. For $\mathrm{C}_{14} \mathrm{H}_{26} \mathrm{~F}_{6} \mathrm{~N}_{2} \mathrm{O}_{5} \mathrm{~S}_{2}$ (480.49): C, 35.00; H, 5.45; N, 5.83. Found: C, 35.35; H, 5.63; N, 5.96. 


\section{References}

1. Hallett, J. P.; Welton, T. Chem. Rev. 2011, 111, 3508.

http://dx.doi.org/10.1021/cr1003248

PMid:21469639

2. Muzart, J. Adv. Synth. Catal. 2006, 348, 275.

http://dx.doi.org/10.1002/adsc.200505273

3. Jain, N.; Kumar, A.; Chauhan, S.; Chauhan, S. M. S. Tetrahedron 2005, 61, 1015. http://dx.doi.org/10.1016/j.tet.2004.10.070

4. Sheldon, R. Chem. Commun. 2001, 2399. http://dx.doi.org/10.1039/b107270f

5. Wasserscheid, P.; Keim, W. Angew. Chem. Int. Ed. 2000, 39, 3772. http://dx.doi.org/10.1002/1521-3773(20001103)39:21<3772::AID-ANIE3772>3.0.CO;2-5

6. Welton, T. Chem. Rev. 1999, 99, 2071. http://dx.doi.org/10.1021/cr980032t PMid:11849019

7. Rogers, R. D.; Seddon, K. R.; Volkov, S. Eds. Green Industrial Applications of Ionic Liquids; Kluwer Academic: Drodrecht, 2002.

8. Ionic Liquids in Synthesis; Wasserscheid, P. Eds.; Wiley-Interscience: New York, 2003.

9. Brandt, A.; Graesvik, J.; Hallett, J. P.; Welton, T. Green Chem. 2013, 15, 550. http://dx.doi.org/10.1039/c2gc36364j

10. Andreani, L.; Rocha, J. D. Braz. J. Chem. Engineer. 2012, 29, 1. http://dx.doi.org/10.1590/S0104-66322012000100001

11. Payagala, T.; Armstrong, D. W. Chirality 2012, 24, 17. http://dx.doi.org/10.1002/chir.21975 PMid:22144292

12. Precht1, M. H. G.; Scholten, J. D.; Neto, B. A. D.; Dupont, J. Curr. Org. Chem. 2009, 13, 1259. http://dx.doi.org/10.2174/138527209789055153

13. Plaquevent, J.-C.; Levillain, J.; Guillen, F.; Malhiac, C.; Gaumont, A.-C. Chem. Rev. 2008, $108,5035$.

http://dx.doi.org/10.1021/cr068218c

PMid:19053329

14. Bica, K.; Gaertner, P. Eur. J. Org. Chem. 2008, 3235. http://dx.doi.org/10.1002/ejoc.200701107

15. Winkel, A.; Reddy, P. V. G.; Wilhelm, R. Synthesis 2008, 999.

16. Ding, J.; Armstrong, D. W. Chirality 2005, 17, 281.

http://dx.doi.org/10.1002/chir.20153

PMid:15844205 
17. Baudequin, C.; Brégeon, D.; Levillain, J.; Guillen, F.; Plaquevent, J.-C.;Gaumont, A.-C.

Tetrahedron: Asymmetry 2005, 16, 3921.

http://dx.doi.org/10.1016/j.tetasy.2005.10.026

18. Baudequin, C.; Baudoux, J.; Levillain, J.; Cahard, D.; Gaumont, A.-C.; Plaquevent, J.-C.

Tetrahedron: Asymmetry 2003, 14, 3081.

http://dx.doi.org/10.1016/S0957-4166(03)00596-2

19. Truong, T.-K.-T.; Van Buu, O. N.; Aupoix, A.; Pegot, B.; Vo-Thanh, G. Curr. Org. Synth. 2012, 9, 53.

http://dx.doi.org/10.2174/157017912798889143

20. Imperato, G.; König, B.; Chiappe, C. Eur. J. Org. Chem. 2007, 1049.

http://dx.doi.org/10.1002/ejoc.200600435

21. Chen, X.; Li, X.; Hu, A.; Wang, F. Tetrahedron: Asymmetry 2008, 19, 1.

http://dx.doi.org/10.1016/j.tetasy.2007.11.009

22. Bonanni, M.; Soldaini, G.; Faggi, C.; Goti, A.; Cardona, F. Synlett 2009, 747.

23. Gausepohl, R.; Buskens, P.; Kleinen, J.; Bruckmann, A.; Lehmann, C. W.; Klankermayer, J.; Leitner, W. Angew. Chem. Int. Ed. 2006, 45, 3689.

http://dx.doi.org/10.1002/anie.200600327

PMid:16708413

24. Allen, C. R.; Richard, P. L.; Ward, A. J.; van de Water, L. G. A.; Masters, A. F.; Maschmeyer, T. Tetrahedron Lett. 2006, 47, 7367.

http://dx.doi.org/10.1016/j.tetlet.2006.08.007

25. Rouch, A.; Castellan, T.; Fabing, I.; Saffon, N.; Rodriguez, J.; Constantieux, T.; Plaquevent, J.-C.; Génisson, Y. RSC Advances 2013, 3, 413.

http://dx.doi.org/10.1039/c2ra21637j

26. Bhat, K. L.; Flanagan, D. M.; Joullié, M. M. Synth. Commun. 1985, 15, 587. http://dx.doi.org/10.1080/00397918508063844

27. Naylor, A.; Judd, D. B.; Scopes, D. I. C.; Hayes, A. G.; Birch, P. J. J. Med. Chem. 1994, 37, 2138.

http://dx.doi.org/10.1021/jm00040a004

28. The solubility was ascertained by dissolving $10 \mathrm{mg}$ of ionic liquid in $1 \mathrm{~mL}$ of solvent. 